\title{
IMPACT ON A FISH ASSEMBLAGE OF THE MAINTENANCE DREDGING OF A NAVIGATION CHANNEL IN A TROPICAL COASTAL ECOSYSTEM
}

\author{
Demarques Ribeiro da Silva Junior, Sérgio Ricardo Santos, Marcelo Travassos and Marcelo Vianna
}

Universidade Federal do Rio de Janeiro

Departamento de Biologia Marinha, CCS - Centro de Ciências da Saúde

(Bloco A, sala ss-054, 21949-900Cidade Universitária, RJ, Brasil)

*Corresponding author: demarquesribeiro@gmail.com

\begin{abstract}
A B S T R A C T
Dredging and dredge-spoil disposal are among the major problems in coastal management. Many of the scientific contributions concerning the impacts of this practice are based on the study of sessile organisms and subtropical environments. We evaluated changes in the composition and abundance of a fish assemblage resulting from dredging and sediment disposal at the mouth and in the adjacent waters of the Caravelas River on the north-eastern coast of Brazil. Samples were collected in two directly impacted and three adjacent areas. Differences among stations were not significant, but the dredged site had the least diverse station, as expected. The stations farthest from the directly impacted areas apparently were not influenced by the coastal work, thus suggesting localised effects. The contribution of the present study is particularly important because of the study area's proximity to others that have high conservation value such as mangrove forests and coral reefs, and the relevance of the subject given the continuing dredging activity.
\end{abstract}

\section{R ESUMO}

A dragagem e descarte de sedimento se destacam como atividades que geram grandes distúrbios aos ecossistemas marinhos e, consequentemente tornam-se um desafio ao manejo e ordenamento costeiro. Grande parte dos estudos que abordam seus impactos é baseada em pesquisas com organismos sésseis e em ambientes temperados, criando uma lacuna no entendimento de seus efeitos sobre a ictiofauna, principalmente nas regiões tropicais. No presente estudo foram avaliadas as alterações na composição e abundância da comunidade de peixes sob influência da dragagem e descarte de sedimento na foz do Rio Caravelas, costa da região Nordeste do Brasil. As amostras foram obtidas em duas estações diretamente afetadas e em três outras áreas adjacentes. Não houve diferença significativa na diversidade média obtida para cada estação, porém a estação correspondente à área dragada apresentou o menor valor dentre as demais. As estações mais afastadas aparentemente não foram influenciadas pelo empreendimento sugerindo efeitos localizados. A contribuição do presente estudo é particularmente importante devido à proximidade com áreas de alto valor de conservação como manguezais e recifes de corais e a relevância do assunto, o qual trata de uma atividade que sugere expansão em vista do desenvolvimento da atividade portuária.

Descriptors: Dredging, Coastal works, Estuarine environments, Sediment disposal, Marine impacts. Descritores: Dragagem, Ambientes estuarinos, Descarte de sedimento, Impactos marinhos.

\section{INTRODUCTION}

The accessibility of coastal ports, fishing harbours, and navigable waterways is vital to the economic growth of coastal regions (ENGLER et al., 1991). Consequently, estuarine areas have traditionally been developed first for these purposes, as surrounding lands are used for human settlement. Since estuaries are rarely naturally deep, dredging becomes vital to maintain navigable depths by preventing the silting of shipping channels (HARVEY et al., 1998).

Dredging and dredge-spoil disposal are among the major problems in coastal management (BORJA et al., 2010). The conflict between the economic importance of estuaries and their ecological significance as rich and complex environments makes it urgent to identify the impacts caused by human activity on the dynamics of estuarine ecosystems, in order to develop efficient methods to minimise them (BLABER, 2000).

These activities have several potential impacts. The continuous removal of the substrate changes the bottom topography as well as the sediment composition. Desprez (2000) reported that after several years of dredging along the French coast of the eastern English Channel, the seabed surface was seriously affected, with reduced species richness, abundance, and biomass. Furthermore, the reconstituted benthic communities formed by recolonisation at the dredging extraction and disposal 
sites were different from the original communities and from the biota found at the control station. Sedimentation caused by dredge-spoil disposal has numerous potential impacts, including the smothering of benthos (although the extent of the impact depends on the mobility of the benthic organisms and the rate of sedimentation) and the suffocation of filter-feeding benthic organisms by large amounts of suspended matter (COLLINSON; REES, 1978; KENNISH, 1992). Extensive sedimentation caused by dredging events was responsible for a decrease in coral diversity and coral cover on intertidal reef flats at Ko Phuket, Thailand (BROWN et al., 1990). Finally, the sediment removed from harbours or estuaries in industrialised regions is usually contaminated with metals, pesticides, and oil, and these pollutants are then transferred to the dumping grounds (YEAGER et al., 2010).

Fish species are more or less associated with the substratum, where they may live, feed, or spawn (WESTERBERG et al., 1996), and therefore respond to changes in this compartment. However, little is understood about the effects of coastal dredging on estuarine fish assemblages (PÉREZ-RUZAFA et al., 2006) which are expected to be less affected by dredging activities than the benthic community, due to their ability to avoid the disturbed area (DESPREZ, 2000). Certain species may be more vulnerable to sedimentation or smothering of eggs on spawning grounds (WESTERBERG et al., 1996). The removal of sediment has also been connected to the loss of fish spawning and nursery habitat. Additionally, many demersal fishes may be affected by the removal of benthos, which is an important food source (DAAN et al., 1990).

In view of these factors, more studies are needed to fully examine the impacts on the ichthyofauna caused by dredging operations and dredge-spoil disposal, and the potential use of the ichthyofauna as a tool to evaluate the health of coastal ecosystems. The main objective of this study was to examine the impacts of a maintenance dredging operation on a tropical coastal ecosystem, Barra do Tomba, located at the mouth of the Caravelas River on the north-eastern coast of Brazil. The research was based on quantitative and qualitative analyses of the ichthyofauna, and addressed the following question: does dredge-spoil dumping have dissimilar impacts on the fish assemblage structure (composition and abundance) at dredged, disposal, and adjacent sites?

\section{Materials And Methods}

\section{Study Site}

The study area is located at the mouth of the Caravelas River and in adjacent areas on the eastern coast of Brazil $\left(17^{\circ} 46^{\prime} \mathrm{S} 39^{\circ} 11^{\prime} \mathrm{W}\right)$. The area includes a large mangrove forest in addition to nearby coral reef structures, such as Coroa Vermelha, São Sebastião Gomes, Paredes Parcel, and the Abrolhos Archipelago (Fig. 1), encompassing an environment rich in biodiversity (ANDRADE; DOMINGUEZ, 2002; PATCHINEELAM; SMOAK, 1999). One of the main characteristics of the eastern Brazilian coast is the predominant influence of tropical waters from the Brazil Current during the summer, characterised by salinities above 36.9 and temperatures between $22^{\circ}$ and $28^{\circ}$ Celsius (LEIPE et al., 1999).

The mouth of the Caravelas River has two entrances, although only one is used by vessels to gain access to Luciano Villas Boas Machado Harbour, locally known as Barra do Tomba. The channel depth ranges from $5-10 \mathrm{~m}$ and has a semi-diurnal tide that ranges from $0.47-3.37 \mathrm{~m}$ (Fig. 1). A study of local current dynamics carried out in 2002 through 2005 found that in waters adjacent to the navigation channel, the main currents are NE and SW with a mean speed of $0.25 \mathrm{~m} / \mathrm{s}$ (maximum of $1.04 \mathrm{~m} / \mathrm{s}$ ) and with waves reaching a maximum of $3.6 \mathrm{~m}$ (mean of $0.45 \mathrm{~m}$ ) (CEPEMAR, 2005). Northward currents occasionally occur in association with cold fronts. The navigation channel contiguous to the mouth of the Caravelas River has predominantly smooth and slightly undulating bed sediment, composed mainly of sand (CEPEMAR, 2004).

\section{Sampling Design}

Surveys were conducted during five periods: (1) March 2006, (2) June 2006, (3) September 2006, (4) March 2007, and (5) June 2007. During this time frame, dredging operations were executed two weeks after period one and also during the fourth period. The fish assemblage was sampled at five stations, designated Control, Channel, Discard, and Plume (A and B) (Fig. 1). The Control station was located north of the dredged area (Channel) and served as a reference site. This area was considered to be uninfluenced by the dredging activity, based on previous studies that showed a predominance of southward currents in the area, which dispersed the sediments in this direction (LEIPE et al., 1999; PATCHINEELAM; SMOAK, 1999). The Channel and Discard stations were located in the impacted area, and were characterised by the dredging activity and spoil disposal, respectively. Plumes A and B were situated south of the Discard station, with Plume B farther from the latter (Fig. 1). The Plume station was divided into two different zones because of the large area that the dispersing sediments could reach, possibly affecting the ichthyofauna to different degrees. 


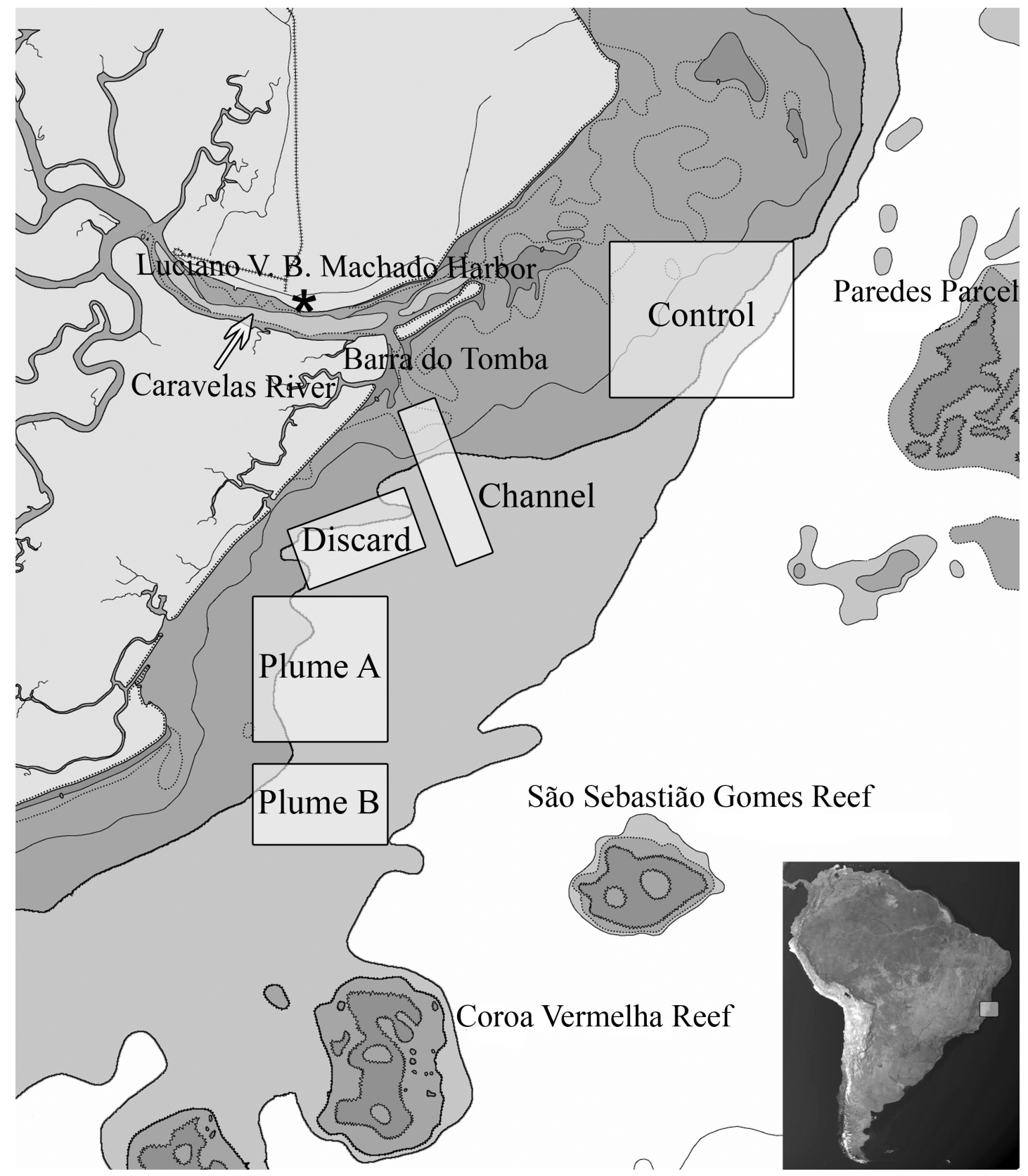

Fig. 1. Map of the mouth of the Caravelas River and the coastal region, showing the stations that were sampled during this investigation and the principal coral reef formations.

At each site, we randomly performed two trawls of $1000 \mathrm{~m}$ (approximately 15-20 minutes each) using a typical fishing boat of the local artisanal fleet. Boat speed was maintained at around 2.0 knots, and the trawls were always carried out during the day. The fish collected were separated and identified to species using specialised literature (e.g., FIGUEIREDO; MENEZES, 2000). Ecological aspects of the species were assessed via specific literature (e.g., VIANNA; ALMEIDA, 2005). No sub-sampling was employed. 
Data Analysis

Firstly, the status of threatened species was assessed using national (MMA, 2004; MMA, 2005) and international (CITES, 2009; IUCN, 2009) lists of threatened and endangered species. For the next step, capture per unit of effort (cpue) was applied as an estimation of abundance (number of individuals trawl $^{-1}$ ) for all analyses.

Fish community structure was characterised using four univariate measures: species richness (total number of species, $S$ ), abundance (Capture per Unit of Effort; number of specimens/trawl), Shannon's diversity index $\left(H^{\prime}\right)$, and Pielou equitability $(J)$ (MARGALEF, 1974). The Analysis of Variance was employed to assess the variability of these measures (ZAR, 1996)

Spatial and temporal differences among the five sites over the five sampling periods were explored using Correspondence Analysis (CA), a multivariate statistical method based on a model of species response to underlying unmeasured environmental gradients (CLARKE; WARWICK, 1994). This analysis was carried out only with species that were dominant throughout the study period, which together contributed $>90 \%$ of the total Index of Relative Importance (IRI) (e.g., SELLESLAGH; AMARA, 2008) (Table 1). This approach removes rare species that increase noise, and only affect the total variation expressed by the eigenvalues but do not alter the interpretation of results.

To analyse the association of each species with a station or a specific sampling event (i.e., occurrence of dredging, or no dredging), an Indicator Species Analysis (ISA) was carried out. Analyses were performed using the programs Statistica 7.1 (StatSoft,
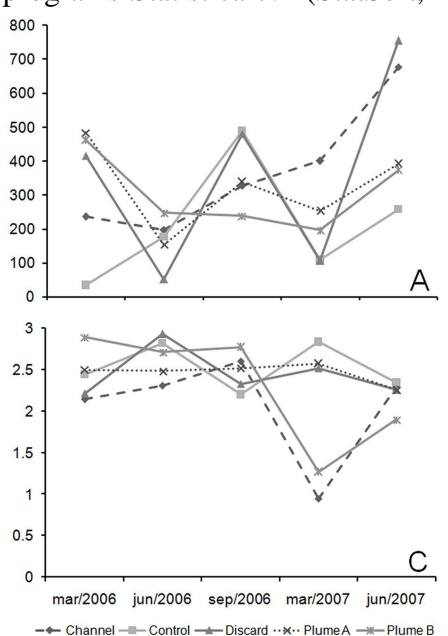

A

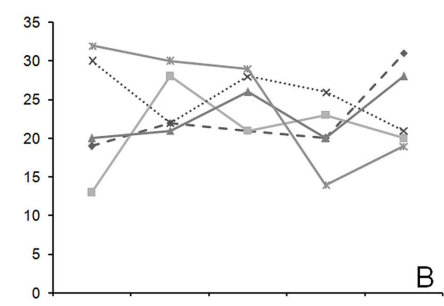

Fig. 2. Temporal succession of abundance (A), species richness (B), Shannon diversity index (C), and Pielou equitability (D) of sampling stations under the influence of dredging at the mouth of the Caravelas River.
2005) and PC-ORD 4 (MCCUNE; MEFFORD, 1999).

Lastly, the significance level of $\alpha=0.05$ was used for all tests.

\section{RESULTS}

A total of 7,582 individuals, representing 79 species in 26 families, were recorded during the five sampling periods. The results showed a high degree of dominance by certain species and families. The seven species captured most often accounted for $49.9 \%$ of total abundance, and Sciaenidae was the most abundant family, contributing $48.1 \%$.

The ariid Genidens barbus and the sciaenids Micropogonias furnieri and Macrodon ancylodon are listed as species under threat or at risk of overexploitation by the Brazilian Environmental Ministry. In addition, the IUCN Red List indicates that for the ray Dasyatis guttata, the available data are insufficient to establish its conservation status.

There was a major change in fish abundance (CPUE) and species richness during the five periods, with no clear evidence that dredge-spoil dumping affected these variables (Fig. 2A and 2B). Both abundance and richness showed the lowest values at the Control site during the first sampling period, carried out two weeks after the dredging operation. The Channel and Discard locations showed the highest abundances during the final sampling period. Shannon's diversity index and Pielou's evenness index varied little over the sampling periods (Fig. 2C and 2D). The lowest diversity measures were associated with the Channel and Plume B stations, concomitant with spoil dumping, and returned to the common range in the next period.

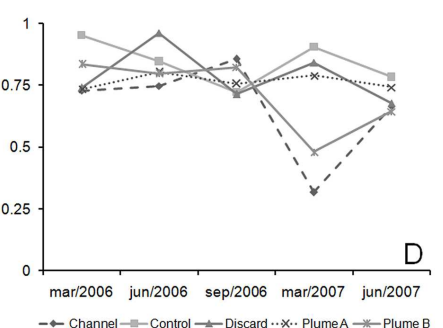


Spatially, the mean diversity values were not significantly different, although they indicated an important difference between the Control station, the directly impacted stations (Channel and Discard), and the adjacent stations (Plumes A and B) (Fig. 3).

The results of the $\mathrm{CA}$ revealed the dissimilarity of the Control station from the other sampling areas during March 2006 and 2007 (Fig. 4), periods associated with dredging and sediment disposal activities. In March 2006, the low total abundance and richness (34 and 13 respectively) were responsible for the dissimilarity of this station, and on March 2007 the reason was the exclusive capture of Chirocentrodon bleekerianus, Isopisthus parvipinnis, Polydactylus virginicus, Stellifer stellifer, and Symphurus tesselatus. On the other hand, Plumes A and B were consistently associated, except for March 2007 when Plume B showed the lowest richness found in this survey. Lastly, there was no proximity of Channel and Discard in the analysis for each sampling period, in consequence of the dissimilar species composition and abundance between these two stations.

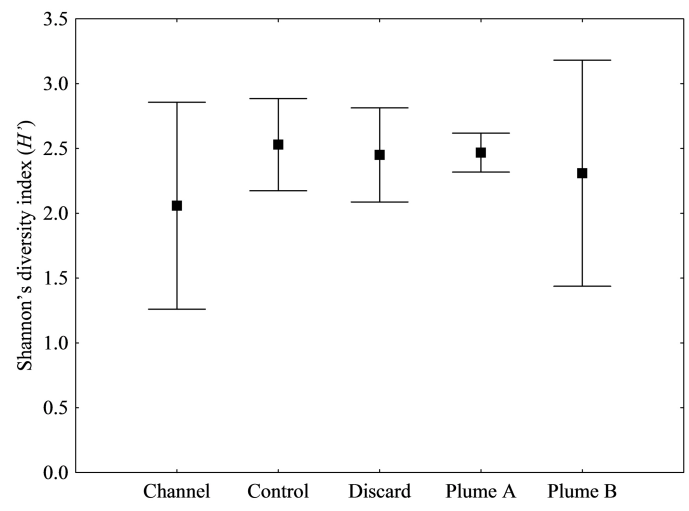

Fig. 3. Mean ( \pm CI; $95 \%)$ variation of Shannon diversity index from each station over the six sampling periods.
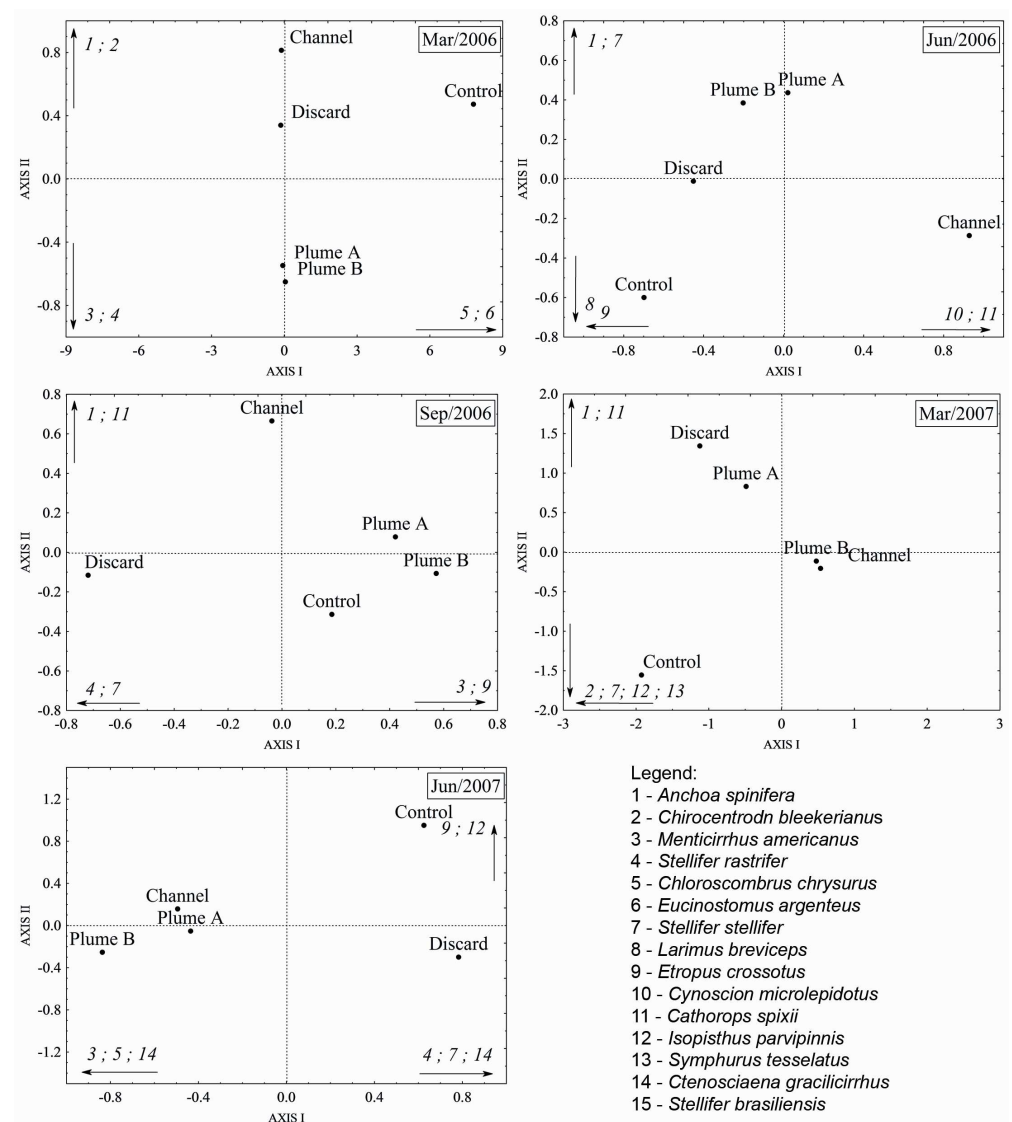

Legend:

1 - Anchoa spinifera

2 - Chirocentrodn bleekerianus

3 - Menticirrhus americar

5 - Chloroscombrus chrysurus

6 - Eucinostomus argenteus

6 - Eucinostomus argen

7 - Stellifer stellifer
8 - Larimus breviceps

8 - Larimus breviceps
9 - Etropus crossotus

10 - Cynoscion microlepidotus

11 - Cathorops spixii

12 - Isopisthus parvipinnis

13 - Symphurus tesselatus
14 - Ctenosciaena gracilicirrh

15 - Stellifer brasiliensis

Fig. 4. Ordination of stations in each sampling period. in biplot representations of the first two axes from the Correspondence Analyses performed on CPUE for species that represented more than $90 \%$ of IRI. 
The Indicator Species Analysis resulted in a total of 19 significant species indicators for the presence or absence of dredging operations (Table 1). Eight of these species were collected only during dredging operations (Cynoscion leiarchus, Diapterus rhombeus, Diplectrum radiale, Eucinostomus argenteus, E. gula, Menticirrhus littoralis, Sphoeroides spengleri, and Synodus foetens).

\section{Discussion}

The first concern that must be addressed in this particular study is the sources of variation that may have influenced the outcomes. The major issue in identifying spatial effects on teleost fishes resulting from coastal activities such as dredging and dredgespoil disposal is that they are vagile organisms and can avoid disturbances by migrating to adjacent areas (PÉREZ-RUZAFA et al., 2006). An investigation becomes more challenging when it takes place in dynamic environments such as estuaries, where the ichthyofaunal assemblage is influenced by seasonal variability. This scenario is specially challenging at the mouth of the Caravelas River, where at the different stations the habitat is highly heterogeneous because of the presence of mangroves and coral reefs.

Having in mind the likely influence of these confounding factors, it was nevertheless possible to identify indicators of the effects resulting from dredge activity. As expected, the Channel station showed the lowest diversity; the observed large $\mathrm{CI}$ is an inevitable consequence of the different situations that were represented during the sampling periods, composed by a variety of temporal circumstances during and after the dredging impact. Under these influences, vagile species such as fish tended to move away from the disturbed area, leaving only a few, more-tolerant species (PÉREZ-RUZAFA et al., 2006), as seen by the short-term decrease in diversity in the Channel during March 2006 and 2007.

Table 1. Mean capture per unit of effort (CPUE) and percentage of indication of significant species from Indicator Species Analysis (ISA).

\begin{tabular}{|c|c|c|c|c|c|c|c|c|c|c|c|c|c|}
\hline \multirow[t]{2}{*}{ Species } & \multicolumn{2}{|c|}{ Channel } & \multicolumn{2}{|c|}{ Control } & \multicolumn{2}{|c|}{ Discard } & \multicolumn{2}{|c|}{ Plume A } & \multicolumn{2}{|c|}{ Plume B } & \multicolumn{2}{|c|}{$\begin{array}{c}\% \text { indication } \\
\text { (relative abundance }+ \text { relative } \\
\text { frequency) }\end{array}$} & \multirow[t]{2}{*}{$\mathrm{p}$} \\
\hline & Mean & SD & Mean & SD & Mean & SD & Mean & SD & Mean & SD & $\begin{array}{l}\text { without } \\
\text { dredging }\end{array}$ & with dredging & \\
\hline Aspistor luniscutis & 3.9 & 9.1 & 0.9 & 2.3 & 1.1 & 1.3 & 2.6 & 2.9 & 0.9 & 1.7 & 58 & 2 & 0.0420 \\
\hline Cathorops spixii & 8.1 & 15.9 & 0.0 & 0.0 & 0.9 & 1.4 & 1.6 & 2.3 & 2.7 & 6.1 & 55 & 0 & 0.0100 \\
\hline Cynoscion leiarchus & 1.0 & 1.9 & 1.2 & 3.0 & 1.8 & 4.5 & 1.6 & 4.0 & 2.8 & 7.0 & 0 & 49 & 0.0020 \\
\hline $\begin{array}{l}\text { Cynoscion } \\
\text { microlepidotus }\end{array}$ & 2.2 & 4.2 & 2.3 & 4.0 & 3.7 & 8.0 & 2.2 & 2.6 & 0.5 & 0.9 & 57 & 1 & 0.0190 \\
\hline Dasyatis guttata & 0.4 & 0.3 & 0.3 & 0.5 & 0.6 & 0.8 & 0.6 & 0.8 & 0.0 & 0.0 & 1 & 64 & 0.0010 \\
\hline Diapterus rhombeus & 0.7 & 1.3 & 0.9 & 1.3 & 0.2 & 0.5 & 0.1 & 0.3 & 0.3 & 0.0 & 0 & 70 & 0.0010 \\
\hline Diplectrum radiale & 0.5 & 1.3 & 0.2 & 0.3 & 0.0 & 0.0 & 0.1 & 0.3 & 0.1 & 0.0 & 0 & 50 & 0.0060 \\
\hline Etropus crossotus & 3.4 & 2.2 & 4.4 & 3.5 & 0.4 & 1.0 & 4.0 & 5.2 & 5.5 & 0.5 & 5 & 79 & 0.0020 \\
\hline $\begin{array}{l}\text { Eucinostomus } \\
\text { argenteus }\end{array}$ & 33.9 & 84.8 & 1.5 & 1.8 & 0.5 & 1.3 & 4.0 & 10.0 & 13.9 & 34.5 & 0 & 70 & 0.0020 \\
\hline Eucinostomus gula & 0.5 & 1.3 & 0.1 & 0.0 & 0.0 & 0.0 & 6.5 & 16.3 & 0.4 & 1.0 & 0 & 40 & 0.0060 \\
\hline Isopisthus parvipinnis & 4.7 & 4.4 & 10.1 & 17.7 & 7.9 & 11.5 & 9.3 & 13.6 & 5.4 & 7.7 & 67 & 15 & 0.0350 \\
\hline Macrodon ancylodon & 0.5 & 1.3 & 2.3 & 5.4 & 1.7 & 2.8 & 1.1 & 2.1 & 0.7 & 0.9 & 66 & 1 & 0.0090 \\
\hline Menticirrhus littoralis & 1.5 & 0.9 & 0.2 & 0.5 & 0.1 & 0.3 & 1.6 & 3.8 & 0.8 & 1.4 & 0 & 67 & 0.0010 \\
\hline $\begin{array}{l}\text { Odontognathus } \\
\text { mucronatus }\end{array}$ & 9.1 & 13.2 & 13.5 & 30.2 & 10.7 & 15.3 & 10.3 & 21.9 & 8.1 & 8.7 & 72 & 8 & 0.0120 \\
\hline $\begin{array}{l}\text { Paralonchurus } \\
\text { brasiliensis }\end{array}$ & 7.9 & 8.1 & 4.4 & 4.8 & 4.5 & 3.8 & 5.0 & 3.9 & 8.2 & 6.3 & 68 & 13 & 0.0040 \\
\hline Peprilus paru & 0.4 & 1.0 & 0.5 & 1.3 & 0.3 & 0.8 & 0.4 & 0.7 & 0.4 & 0.7 & 45 & 0 & 0.0270 \\
\hline Sphoeroides spengleri & 0.4 & 1.0 & 0.1 & 0.3 & 0.3 & 0.8 & 0.4 & 1.0 & 0.0 & 0.0 & 0 & 40 & 0.0080 \\
\hline Stellifer rastrifer & 3.4 & 5.0 & 1.0 & 1.7 & 13.2 & 21.0 & 1.5 & 1.4 & 1.0 & 0.3 & 63 & 3 & 0.0460 \\
\hline Synodus foetens & 0.4 & 1.0 & 0.0 & 0.0 & 0.1 & 0.3 & 0.3 & 0.8 & 0.2 & 0.5 & 0 & 40 & 0.0040 \\
\hline
\end{tabular}

$\mathrm{SD}=$ standard deviation 
The other directly impacted area was the Discard station; this site showed a smaller range in the confidence interval but a higher mean value for the Shannon diversity index. One might suggest that the spoil dumping had only a small impact at this station. However, it seems that the effects at this station had the opposite effect on teleost fishes than on the benthic fauna. Sediment disposal may have increased the availability of food in the sediment, acting as an attractive factor (HARVEY et al., 1998) for ichthyofauna and increasing diversity, similarly to the findings of Pérez-Ruzafa et al. (2006) for a corresponding Discard site.

The sampling stations farthest from the directly impacted areas (Control, Plumes A and B) apparently were not influenced by the dredge and dredge-spoil disposal activities, and were dissimilar to the other areas, independently of the period. These stations may be functioning as refuge zones, receiving organisms that are sensitive to disturbances. The association of Etropus crossotus with dredge events at the Control and Plume B stations supports this hypothesis, in view of the close relationship of this species to the sediment (ALLEN; BLATZ, 1997), and changes in the substrate are presumed to strongly influence its presence (CONSTANTINO et al., 2009).

On the other hand, some species were associated with the directly impacted areas during the dredging period. Bolam and Rees (2003) stated that naturally unstable ecosystems such as estuaries are composed of a large number of opportunistic species (ELLIOT et al., 2007). These species are responsible for a rapid recolonisation process that accelerates the reconstitution of disturbed ecosystems, mitigating the impacts of dredging (BEMVENUTI et al., 2005; BOLAM; REES, 2003; SMITH; RULE, 2001). Among the species related to the presence of dredging work, four were captured mostly at the Channel station: Diplectrum radiale, Eucinostomus argenteus, Sphoeroides spengleri, and Synodus foetens. Therefore, these species may be responsible for a similar recolonisation process at directly impacted stations, because of their resistance to disturbance.

In conclusion, the effects on the ichthyofaunal assemblage resulting from dredge and dredge-spoil disposal appear to be localised at the directly impacted stations. Nevertheless, dredging and dredge-spoil disposal in estuarine ecosystems are a matter of utmost importance and should be evaluated with care, given the presence of economically important species at risk of over-exploitation. The present case is especially relevant because of the proximity of important ecosystems to the mouth of the Caravelas River, including coral reefs and mangrove forests that have high conservation value. Due to the sampling design, the recovery time could not be evaluated, but it was possible to indicate species related to this process. This is an attractive approach that must be considered, in order to support management actions while dredging and spoil disposal continue to be widespread activities.

\section{ACKNOWLEDGEMENTS}

This work was funded by Aracruz Celulose, which has given permission for the publication of the results. The study was undertaken in conjunction with CEPEMAR, which was responsible for the biological monitoring framework of this activity. We are also grateful to the Laboratory of Fishery Biology and Technology of the Federal University of Rio de Janeiro.

\section{REFERENCES}

ALLEN, R. L.; BLATZ, D. M. Distribution and microhabitat use by flatfishes in a Louisiana estuary. Environ. Biol. Fishes, v. 50, p. 85-103, 1997.

ANDRADE, A. C. S.; DOMINGUEZ, J. M. L. Holocene barrier island/lagoon system at Caravelas strandplain. J. coast. Res., v. 42, p. 132-141, 2002.

BEMVENUTI, C. E.; ANGONESI, L. G.; GANDRA, M. S. Effects of dredging operations on soft bottom macrofauna in a harbor in the Patos Lagoon estuarine region of Southern Brazil. Braz. J. Biol., v. 65, p. 573$581,2005$.

BLABER, S. J. M. Tropical estuarine fishes: ecology, exploitation and conservation. Oxford: Blackwell Science, 372 p. 2000.

BOLAM, S. G.; REES, H. L. Minimizing impacts of maintenance dredge material disposal in the coastal environment: a habitat approach. Environ. Manag.,v. 32, p. 171-188, 2003

BORJA, A.; DAUER, D. M.; ELLIOTT, M.; SIMENSTAD, C. A. Medium- and long-term recovery of estuarine and coastal ecosystems: Patterns, rates and restoration effectiveness. Estuaries and Coasts, v. 33, p. 12491260,2010

BROWN, B. E.; LE TESSIER, M. D. A.; SCOFFIN, T. P.; TUDHOPE, A. W. Evaluation of the environmental impact of dredging on intertidal coral reefs at Ko Phuket, Thailand, using ecological and physiological parameters. Mar. Ecol. Progr.Ser., v. 65, p. 273-281, 1990.

CEPEMAR - Meio Ambiente. Caracterização geológica do fundo marinho no canal de acesso da Barra do Tomba - Caravelas. Vitória: CEPEMAR Technical Report CPM RT 051/04, Vitória, Brazil, 2004.

CEPEMAR - Meio Ambiente. Hidrodinâmica e concentração de sedimentos em suspensão na zona costeira de Caravelas (BA). CEPEMAR Technical Report CPM RT 212/05, Vitória, Brazil, 2005.

CITES - Conservation on International Trade in Endangered Species of Wild Fauna and Flora. CITES species database.2009.<http://www.cites.org/eng/resources/spec ies.html>. Accessed online October 10, 2010.

CLARKE, K. R.; WARWICK, R. M. Change in marine communities: an approach to statistical analysis and $\mathrm{j}$ United Kingdom: Bourne Press, 1994. 859 p. 
COLLINSON, R. I.; REES, C. P. Mussel mortality in the Gulf of La Spezia, Italy. Mar. Pollut. Bull., v. 2, p. 99101, 1978.

CONSTANTINO, R.; GASPAR, M. B.; TATA-REGALA, J.; CARVALHO, S.; CÚRDIA, J.; DRAGO, T.; TABORDA, R.; MONTEIRO, C. C. Clam dredging effects and subsequent recovery of benthic communities at different depth ranges. Mar. Environ. Res., v. 67, p. 89-99, 2009.

DAAN, N.; BROMLEY, P. J.; HISLOP, J. R. G.; NIELSEN, N. A. Ecology of North Sea fish. Neth. J. Sea Res., v. 26, p. 343-386, 1990.

DESPREZ, M. Physical and biological impact of marine aggregate extraction along the French coast of the Eastern English Channel: short- and long-term postdredging restoration. ICES J. Mar. Sci., v. 57, p. 14281438, 2000.

ELliOT, M.; WHITFIELD, A. K.; POTTER, I. C.; BLABER, S. J. M.; CYRUS, D. P.; NORDLIE, F. G.; HARINSON, T. D. The guild approach to categorizing estuarine fish assemblages: a global review. Fish and Fish., 8:241-268, 2007.

ENGLER, R.; SAUNDERS, L.; WRIGHT, T. Environmental effects of aquatic disposal of dredged material. Environ. Prof., v. 13, p. 317-325, 1991.

FIGUEIREDO, J. L.; MENEZES, N. A. Manual de Peixes Marinhos do Sudeste do Brasil VI, Teleostei (5). São Paulo: Museu de Zoologia da Universidade de São Paulo, 2000. 116 p.

HARVEY, M.; GAUTHIER, D.; MUNRO, J. Temporal changes in the composition and abundance of the macrobenthic invertebrate communities at dredged material disposal sites in the Anse à Beaufils, Baie des Chaleurs, Eastern Canada. Mar. Pollut. Bull., v. 36, p. 41-55, 1998.

IUCN - International Union for Conservation of Nature and Natural Resources. The IUCN Red List of Threatened Species. 2009.. <http://www.iucnredlist.org $>$. Accessed online October 10, 2010:

KENNISH, M. J. Ecology of estuaries: anthropogenic effects. Boca Raton: CRC Press, 1992. 512 p.

LEIPE, T.; KNOPPERS, B.; MARONE, E.; CAMARGO, R. Material transport in coral reef waters of the Abrolhos Bank, Brazil. Geo -Marine Letts, v. 19, p. 186-195, 1999.

MARGALEF, R. Ecología. Barcelona: Omega, 1974. 966 p.

MCCUNE, B.; MEFFORD, M.J. PC-ORD: multivariate analysis of ecological data for Windows v4.01. Oregon: MjM Software Design, 1999.
MMA - Ministério do Meio Ambiente. Normative Instruction $n^{\circ} 5$ 04/21/2004. Brasília, DF., Brasil, 2004. MMA - Ministério do Meio Ambiente. Normative Instruction $n^{\circ} 52$ 11/08/2005. Brasília, DF.,Brasil, 2005.

PATCHINEELAM, S. R.; SMOAK, J. M. Sediment accumulation rates along the inner eastern Brazilian continental shelf. Geo Mar. Lett., 19:196-201, 1999.

PÉREZ-RUZAFA， A.; GARCÍA-CHARTON, J. A.; BARCALA, E.; MARCOS, C. Changes in benthic assemblages as a consequence of coastal works in a coastal lagoon: The Mar Menor (Spain, Western Mediterranean). Mar. Pollut. Bull., v. 53, p. 107-120, 2006.

SELLESLAGH, J.; AMARA, R. Environmental factors structuring fish composition and assemblages in a small macrotidal estuary (eastern English Channel). Estuar. coast. Shelf Sci., v. 79, p. 507-517, 2008.

SMITH, S. D. A.; RULE, M. J. The effects of dredge-spoil dumping on a shallow water soft-sediment community in the Solitary Islands Marine Park, NSW, Australia. Mar. Pollut. Bull., v. 42, p. 1040-1048, 2001.

STATSOFT. STATISTICA v7.1. Tulsa: StatSoft Inc., 2005.

VIANNA, M.; ALMEIDA, T. Bony fish bycatch in the Southern Brazil pink shrimp (Farfantepenaeus brasiliensis and F. paulensis) fishery. Braz. Arch. Biol. Tech., v. 48, p. 611-623, 2005.

WESTERBERG, H.; RONNBACK, P.; FRIMANSSON, H. Effects of suspended sediments on cod eggs and larvae and on the behaviour of adult herring and cod. ICES Council Meeting Papers, E:26, 1996.

YEAGER, K. M.; BRINKMEYER, R.; RAKOCINSKI, C. F.; SCHINDLER, K. J.; SANTSCHI, P. H. Impacts of dredging activities on the accumulation of dioxins in surface sediments of the Houston Ship Channel, Texas. J. coast. Res., v. 26, p. 743-752, 2010.

ZAR, J. H. Bioestatistical analysis. Upper Sddle River, N.J.: Prentice-Hall, 1996. 663 p.

(Manuscript received 06 January 2011; revised 22 July 2011; accepted 20 October 2011) 